\title{
The impact of COVID-19 on education provision to indigenous people in Mexico
}

Elida Sánchez-Cruz 1

Alfred Masinire 2

Enrique Vez López ${ }^{1}$

1 Universidad Veracruzana / School of Languages, Xalapa - México

${ }^{2}$ University of the Witwatersrand / Department Wits School of Education, Johannesburg - South Africa

As a result of the COVID-19 pandemic, measures have been taken globally to shut down schools at all levels and move education to the online arena, which entails a strong dependence on access to the internet and electronic gadgets. Measures such as these are bound to deepen already existing inequality and bring about major disruptions in the students' learning process. In this context, the makeup of our diverse Mexican society and school communities calls for a political framework that promotes equal education and ensures a way of constructing knowledge that is accessible to all; a perspective in education that respects traditional groups and cultures, especially those who are usually financially disadvantaged, such as indigenous people. This article examines measures taken to support provision of online education, in general, and indigenous groups, in particular. The data collection approach to support the findings consisted of reviewing official websites from UNESCO, the Mexican Ministry of Education, and three states with the largest number of indigenous people (IP). The findings suggest that the production of TV programs and school booklets in indigenous languages show a considerable effort to reach out to indigenous communities throughout the country. Nevertheless, the measures taken by the national and state governments may still be deemed limited and somewhat biased in favor of monolingual students.

Keywords: COVID-19 pandemic; education; Mexico; indigenous people; language.

\section{0 impacto da COVID-19 na oferta de educação para alunos indígenas no México}

A pandemia da COVID-19 levou a medidas como o fechamento de todas as escolas em todos os níveis educacionais, e a transferência de suas atividades para a arena online, o que implica uma forte dependência do acesso à Internet e dispositivos eletrônicos. Medidas como essas tendem a aprofundar a desigualdade já existente e causar grandes interrupções no processo de aprendizagem dos alunos. Nesse contexto, a configuração da diversificada sociedade mexicana e das comunidades escolares exige uma estrutura política que promova a educação igualitária e garanta uma forma de construção do conhecimento acessível a todos; uma perspectiva de educação que respeite os grupos e culturas tradicionais, especialmente aqueles que geralmente são desfavorecidos financeiramente, como os indígenas. Este artigo examina as medidas tomadas para apoiar a oferta de educação online, em geral, e a oferta para grupos indígenas, em particular. A abordagem de coleta de dados para apoiar os resultados consistiu na revisão dos sites oficiais da UNESCO, do Ministério da Educação mexicano e de três estados com o maior número de povos indígenas. Os resultados sugerem que a produção de programas de TV e livretos escolares em línguas indígenas falam de um esforço considerável para alcançar as comunidades indígenas em todo o país. No entanto, as medidas tomadas pelos governos nacional e estaduais podem ser consideradas ainda limitadas e um tanto tendenciosas a favor dos alunos monolíngues.

Palavras-chave: pandemia da COVID-19; educação; México; povos indígenas; linguagem. 


\section{El impacto de la COVID-19 en la provisión de educación a estudiantes indígenas en México}

Como resultado de la pandemia de COVID-19, se han tomado medidas a nivel mundial para cerrar las escuelas en todos los niveles y trasladar la educación al ámbito en línea, lo que implica una fuerte dependencia del acceso a internet y dispositivos electrónicos. Medidas como estas seguramente profundizarán la desigualdad ya existente y provocarán grandes interrupciones en el proceso de aprendizaje de los estudiantes. En este contexto, la conformación de nuestra diversificada sociedad y de las comunidades escolares mexicanas exige un marco político que promueva la educación equitativa y asegure una forma de construcción del conocimiento accesible a todos; una perspectiva educacional que respete los grupos y culturas tradicionales, especialmente aquellos que suelen estar en desventaja económica, como los pueblos indígenas. Este artículo examina las medidas adoptadas para apoyar la provisión de educación en línea, en general, y a los grupos indígenas, en particular. El enfoque de recopilación de datos para respaldar los hallazgos consistió en revisar los sitios web oficiales de la UNESCO, del Ministerio de Educación de México y de tres estados con mayor número de pueblos indígenas (PI). Los resultados sugieren que la producción de programas de televisión y folletos escolares en lenguas indígenas demuestra un esfuerzo considerable para llegar a las comunidades indígenas de todo el país. Sin embargo, las medidas tomadas por los gobiernos nacional y de los estados pueden considerarse aún limitadas y algo sesgadas a favor de los estudiantes monolingües.

Palabras clave: pandemia de COVID-19; educación; México; pueblos indígenas; idioma.

\section{INTRODUCTION}

Velasco Pavón (2014) states that IP can be defined as native or aboriginal people, these are descendants of the original inhabitants of Mexico, and that is how they must be understood in this paper. Even though this definition is not widely accepted, it is possible to identify a predominant characteristic that indigenous groups share:a painful history of colonialism (Velasco Pavón, 2014). IP can also be defined along some cultural lines; for instance, they usually prefer a non-dominant social organization to a hierarchical structure; a very strong attachment to their land; and a tendency to work in small family businesses or be self-employed (Velasco Pavón, 2014).

In Mexico, poverty, malnutrition, low living standards, racism, discrimination to their culture and language, exploitation, oppression, limited or no access to education and health services are some of the issues IP have had to endure with for centuries (Tauli-Corpuz, 2005). These social and cultural demands gained momentum with the Zapatista uprising of 1994, which mainly demanded: a) autonomy (municipal or regional), b) integration of both conservation and development, and c) recognition of their rights as indigenous communities and culture (Paré, Robles \& Cortes, 2002). Ever since, several indigenous organizations have joined efforts in this movement and have organized themselves to "demand social justice, recognition of diversity, construction of a new relationship with nature and transformation of the values associated with consumerism and individualism that govern the life of industrial society" (Paré et al., 2002 p. 4).

As a response, international and national policies demanding a full recognition of their existence, their languages, and their historic and cultural rights have been implemented, which seems to have led to a recent changes in the Mexican political landscape and a renewed government willingness to integrate all those regions in the country that have been traditionally neglected and marginalized. This resulted in the creation of new spaces for dialogue, participation, and hopefully, prosperity for those most marginalized. This unique background may help us understand the scope of the initiatives implemented by the government to ensure the education of IP in the wake of the COVID-19 pandemic. 
In this paper, we present a review of official information from United Nations Educational, Scientific and Cultural Organization (UNESCO), the Mexican Ministry of Education, and the three State Ministries of Education with the largest number of IP in order to analyse the limitations of these measures.

\section{BACKGROUND}

The United Nations (n.d.) describes IP as heirs and practitioners of unique cultures which have preserved their social, cultural, economic, and political characteristics different from those of the dominant society that surrounds them. Despite their cultural wealth and belonging to the locality; IP have had to seek their recognition for basic rights such as education. This is how international organizations such as the UN and UNESCO work to promote international legal frameworks that protect and promote their human rights.

Mexico has signed and ratified different instruments, both internationally and nationally, which makes it a country with a political framework that recognizes equality among all human beings. Thus, all the people who live in the country, regardless of their culture, skin colour, gender, or language, must enjoy the same rights and guarantees. The political framework that warrants the right to education is set out below, starting with international and national instruments. After that, the socio-educational context is described. As stated above, this study discusses and analyses the impact of Coronavirus Pandemic on education of the IP. The study concludes by way of recommendations that may be instituted to alleviate the educational plight of IP in the aftermath of the COVID-19 pandemic.

At the international level, many instruments recognize the rights of IP to education. Some of them are the Human Rights Universal Declaration (HRUD), the Convention on the Rights of the Child and its Committee (CRCC), the International Convention on the Elimination of All Forms of Racial Discrimination (ICEAFRD) and the United Nations Declaration on IP (UNDIP), and the Convention No. 169 on Indigenous and Tribal Peoples in Independent Countries (CITPIC). Mexico signed the HRUD on December 10th, 1948 (CEDHNL, n. d.). The HRUD is a document that works to plan a global action in favour of liberty and equality. Article 26 of the HRUD establishes the right to education as a human right (United Nations International Children's Emergency Fund [UNICEF], 2018). As a consequence, all the people living in the Mexican territory have the right to an education of the same quality.

In addition, the CRCC, in effect in Mexico since 1990 (Castañeda, 2015), makes reference, in its Principle 7, to the right to free education and mentions that education must be carried out through the use of the students' culture; that is, education must take into account the context and environment that surrounds the students to promote learning. Also, Mexico signed the ICEAFRD in 1975 (Castañeda, 2015). States parties, such as Mexico, are obliged not to be the cause of racial discrimination against individuals, groups of people or institutions; that is to say, the population should receive the same treatment and benefit without making distinctions for skin color.

The UNDIP was approved in Mexico in 2007 and frames the parameters for the respect of their rights in terms of self-determination, culture, language, education, and their own development as indigenous communities. Finally, the CITPIC, which Mexico ratified and implemented on September 5, 1991, guarantees the education of IP at all levels and adds that the education of children must be 
offered in their own language or in the language most commonly spoken in the group to which they belong (Castañeda, 2015); thus establishing obligations for States in terms of education, cultural integrity, and respect for the languages spoken in their territory.

On the other hand, there are also the national instruments that frame policies and laws in favor of the education of the entire Mexican population. They are the Political Constitution of the United Mexican States (PCUMS), the General Law of Linguistic Rights of Indigenous People (GLLRIP), the General Education Law and the General Law on the Rights of Girls, Boys, and Adolescents (CEDHNL, n.d.). The PCUMS describes a unique and indivisible nation while it also recognizes its multicultural composition. Thus, federal, state, and municipal institutions must promote equality of opportunities for-natives and eliminate any discriminatory practices. Also, in Article 3, free education is recognized and guaranteed for all people and for all levels that constitute basic compulsory education: preschool (3 to 5 years of age), elementary (6 to 11), middle school (12 to 14) and high school (15 to 17) (National Institute for the Evaluation of Education, 2017).

\subsection{Socio-educational context}

Indigenous communities are at a structural disadvantage due to the limited access they have to academic training (CONAPRED, 2020). Adequate academic training can be seen as a tool to be acquired in the workplace. However, since IP regularly live in areas of high vulnerability (Instituto Nacional de Estadística, Geografía e Informática [INEGI], 2015), they have limited access to education in their own language (INEGI, 2015) and educational instruction may not be adequate (UNESCO, 2018) as one same teacher is in charge of various educational levels. This situation, in turn, affects stereotypes that associate IP with a lack of willingness and/or a low capacity to work.

According to data from the Intercensal Survey (INEGI, 2015), Mexico had a population of 119, 530, 753 , with 25.7 million (21.5\% of the national population) who identify themselves as indigenous people. 7.2 million of them speak an indigenous language in addition to Spanish (bilinguals); 909,356 spoke only their own indigenous language (monolinguals), and the rest spoke only Spanish (monolinguals in Spanish). In Mexico, the lack of command of Spanish can turn out to be problematic as it inhibits access to health services, justice, and even education itself, since the institutions handle Spanish as the only language of communication. In this context, the States with the largest population speaking an indigenous language are Oaxaca, Yucatan, and Chiapas, with $42.6 \%$ of the total (INEGI, 2015; National Population Commission, 2015).

This state of vulnerability in which IP live has an impact on all aspects of IP's lives. As an example of this, The INEGI (2015) indicates that the coverage of the electric energy service is $95.7 \%$ in the homes of IP, while for the rest of the nation, access is $98.7 \%$. Thus, access to electricity, a commodity in almost all households in the country, shows a difference of three points between the non-indigenous and indigenous population. Another example has to do with access to information and communication technologies (ITC) in homes, which at the national level is described in table 1. 


\begin{tabular}{|c|c|c|c|c|c|}
\hline Population & Television & Cell phone & Flat screen TV & Computer & Internet \\
\hline No indigenous & $93 \%$ & $78.6 \%$ & $45 \%$ & $32.9 \%$ & $32.9 \%$ \\
\hline Indigenous & $72.5 \%$ & $52.6 \%$ & $20.1 \%$ & $11 \%$ & $9.8 \%$ \\
\hline
\end{tabular}

Source: Elaborated by the authors based on INEGI (2015, p. 84).

According to table 1, the difference in access to technological tools between the non-indigenous population and the indigenous population is well over $20 \%$ in three areas; with a greater difference in terms of access to television and cell phones. However, access to a computer and the internet is low in both populations. Regarding poverty levels, the National Council for the Evaluation of Social Development Policy, a.k.a. CONEVAL (2019) indicates that $69.5 \%$ of the indigenous population is in a situation of poverty; while 39\% of the non-indigenous population is in the same situation. Regarding extreme poverty, CONEVAL (2019) also informs that one in four IP, and one in twenty non-IP, are in this dire situation.

UNICEF (2018) estimates that more than half of the IP lived in rural locations. According to the National Institute for the Evaluation of Education (INEE, 2017), this implies that they are more exposed to unfavourable educational contexts. In indigenous and rural municipalities, public education services are the responsibility of the State. They have some characteristics in common, such as reduced enrolment, shortage of relevant materials, monolingual teachers in Spanish, and teachers responsible for more than one grade of school—these are known as multi-grade schools (INEE, 2017). In some cases, one same teacher meets the needs of all grades (these are known as unit schools); while in other cases, the multi-grade scheme caters for two thirds of indigenous primary schools nationwide. According to research, a lack of materials in the local language is a problem as well (INEE, 2017).

The above precarious characteristics are reflected in the school permanence, dropout, and learning levels of indigenous students, which is already low in Mexico; however, the difference is even worse in rural areas (INEE, 2017).

As can be appreciated in the preceding paragraphs, IP live in a situation well below the national average despite living in a country with policies in favor of multiculturalism and non-discrimination. In this regard, in 2011, the National Council for the Prevention of Discrimination, a.k.a. CONAPRED, (2011) determined that the national institution in charge of the education system in the country committed acts of discrimination against indigenous girls and boys through the National Evaluation of Academic Achievements in School Centers (ENLACE). The resolution was based on two arguments; on the one hand, the test was only in Spanish and on the other, the questions referred to activities or events of urban life (CONAPRED, 2011). In other words, multicultural differences in terms of language and the social context of indigenous groups were not considered. A metrocentric bias in terms curriculum content, pedagogical presentation and evaluative criteria amounts to educational exclusion of those who do not reside in the urban areas, and this affects the IP, in particular. 


\subsection{Coronavirus Pandemic and its impact on education}

The recently discovered coronavirus (COVID-19) causes an infectious disease, which has now spread worldwide, turning into a pandemic, with a strong global impact in terms of health and education. According to the World Health Organization (WHO, 2020, p. 6), "the disease spreads primarily from person to person through small droplets from the nose or mouth, which are expelled when a person with COVID-19 coughs, sneezes, or speaks". This disease is so infectious that as of May 21st., 4, 993, 470 cases were confirmed, this number includes 327, 738 confirmed deaths in 215 countries (WHO, May 21th, 2020). In Mexico, at the time this paper was written, official reports had confirmed 78, 023 positive cases, 8, 597 deaths and 54,383 recoveries as of May 28, 2020 (Gobierno de México, 2020). While the official reports in Mexico do not explicitly show the number of IP infected, one would think that the IP have been proportionally impacted, if we consider the trend in the United States of America where the poor Afro-American have higher rates of infection and death.

As a consequence of COVID-19, governments around the world have taken measures to control the pandemic by temporarily closing schools, among other public institutions. UNESCO (May 10th, 2020) calculates that these closures are impacting over $72 \%$ of the students around the world since some of the countries are implementing localized measures. This impact is particularly severe on vulnerable and marginalized students and their families (UNESCO, May 10 ${ }^{\text {th }}, 2020$ ).

To reduce the impact of school closures and, at the same time, facilitate inclusive learning opportunities for children and youth during this pandemic crisis, UNESCO (2019) launched the Global Education Coalition, with the aim of providing resources online. Although it is a promising initiative, these online services are only accessible to people with a computer and internet service on hand; thus, such initiative perpetuates systems of technological and social inequality (Tollefson, 2009). Critical theory highlights the concept of power, particularly in schools, which are institutions involved in reproducing inequality and the struggle to bring greater forms of social justice (Tollefson, 2009). Inequality is largely invisible, due to ideological processes that make inequality seem to be the natural condition, in this case, of IP.

\section{METHODOLOGY}

For this study, document analysis was used in order to collect appropriate data in support of this research. The use of documentary research and of documentary sources obtained from official websites is quite useful in social research and more cost effective than social surveys, in-depth interviews, or participant observation (Mogalakwe, 2009). However, the major limitation is that the data is of a secondary nature and its original purpose is not for research. In addition, document analysis was also selected for safety reasons (Cohen, Manion \& Morrison, 2007). In the context of the COVID-19 pandemic, safety protocols of maintaining social distance, and in some cases strict lockdown regulations, made it impossible to conduct face to face interviews because of the danger of the pandemic and the risks of infection in real life interviews.

In an attempt to contain the spread of the COVID-19 pandemic, most governments, including that of Mexico, have closed educational institutions. At the same time, there was a pressing need 
to continue offering teaching and learning programs by adopting remote online national learning platforms and tools which national governments have adopted, as recommended by UNESCO. (https://en.unesco.org/covid19/educationresponse/nationalresponses). For this study, documents submitted by the national government of Mexico to the UNESCO international official website were reviewed. Nationally, Mexico is regulated by a Federal Ministry of Education, which articulates 32 State Ministries. However, only the three State Ministries of Education with the largest percentage of indigenous people were purposefully selected and reviewed: Oaxaca (32\%), Yucatán (28.9\%) and Chiapas (27.9\%) (they are followed by Quintana Roo 16\% and Guerrero 15.3\%) (Comisión Nacional de la Población, 2015; INEGI, 2015). In addition to Spanish, 68 indigenous languages and 364 language varieties are spoken in the national territory, which make Mexico quite a diverse and challenging context.

To limit the study (Cohen, Manion \& Morrison, 2007), only those documents available to facilitate indigenous education during the COVID-19 pandemic in the months of March, April and May of 2020 were considered. These criteria guided the selection of documents from UNESCO, the Mexican Ministry of Education official website, and the three State Ministries of Education, to be analysed. Considering the policy framework that surrounds education in a multicultural country such as Mexico, the goal of this study was to make sense of their meaning and significance (Scott, 2006) for indigenous groups. By analysing these documents, this study was able to ascertain the extent to which the educational needs of indigenous people have been addressed during the COVID-19 pandemic. However, the study acknowledges the limitations of official policy documents in providing useful data for research and would therefore suggest undertaking future qualitative research approaches which would generate primary data through qualitative interviews.

\section{RESULTS AND DISCUSSIONS}

As a result of the COVID-19 pandemic, Mexico was one of the latest countries in shutting down schools on March 23 ${ }^{\text {rd }}$ 2020; affecting 37, 589, 611 learners (UNESCO, May 10, 2020). Distribution of the school population by gender is as follows: 18, 794, 960 females and 18, 794, 651 males in kindergarten, elementary school, secondary school, high school, and tertiary. As learners cannot go without education for such a long time, each country, just like Mexico, implemented strategies to comply with the social distance protocols that COVID-19 reclaims.

For example: Angola, Botswana, and Burkina Faso offer TV education; Japan provides a collection of platforms for teaching and learning; New Zealand uses the following tools: an official platform, learning resources and TV shows; Canada utilizes at least 12 different sources to promote education; while Gibraltar, Dominica, and Chile offer only programmes online (UNESCO, 2019). In other words, different strategies are being implemented worldwide. Within this context, Mexico also provides learning platforms for its multicultural society. According to UNESCO (2019) the following tools are available (Box 2). 


\begin{tabular}{lcc} 
Material & Available in Spanish & Available in an indigenous language \\
\hline Learn 2.0. To promote TICS and digital skills & yes & no \\
Learning at home using your TV. Programmes also & yes & no \\
available online & & no \\
Books & yes & no \\
Secondary T-V & yes &
\end{tabular}

Source: Elaborated by the authors based on UNESCO (2019).

A closer description of this material states that Learn 2.0 was already designed back in 2018. This platform provides seven types of links for teachers and students to promote the use of ICT, online resources, strategies, videos with specialists, and quality teaching practices. No further information is available. Learning at home using your TV broadcasts the schedule of the (current) week for each of the grades going from kindergarten to high school. These TV shows are also available on a popular video platform to be reviewed when necessary. The link to the books presents a collection for each level of education for students, teachers, and parents. It is divided as follows: 12 for kindergarten, 45 for elementary school, 38 for Secondary T-V. These books were published back in 2019 for the current year. Secondary T-V is a complete platform that was created for this type of education in 2015, with a great variety of digital resources for students, teachers, parents, and the community.

In addition, UNESCO's (April, 27 ${ }^{\text {th }}, 2020$ ) web page entitled Frente Educativo (Educational Front) provides a video to be used in English, with subtitles in Spanish, with general information about COVID-19. This website includes a link entitled: Material in indigenous languages to prevent Coronavirus. In this link, one can find recordings with a length of one to four seconds of a person saying: Stay home, in 63 indigenous Mexican languages. Although this link is directed to educational institutions, no information referring to the education of IP is provided. The website of the Ministry of Education (Secretaria de Educación Pública, 2020) provides the same information as above.

According to Mr. Moctezuma, head of the Ministry of Education, $300 \mathrm{TV}$ programs of 30 minutes each were supposed to be produced in Spanish to reduce the impact of COVID-19 in education. These programs make reference to the videos available in the platform Learning at Home using your TV set. In a memorandum dated on April 27, 2020, the Ministry of Education stated that inclusion is a fundamental part of the program Learning at Home and claimed, this time, that 1, 140 programs were going to be prepared in Spanish for television. In the same memorandum, Mr. Moctezuma also declared that 444 programs for radio had been designed in 15 indigenous languages; however, no evidence of this was found in the website. These findings are similar to those of Merino (2015), who declared that indigenous programs are characterized by a lack of operative rules and, therefore, impact results.

Regarding the context and the access to ICT (INEGI, 2015), the Ministry of Education (SEP, April 24th, 2020) described a radio strategy to foster education in 15 indigenous communities using their own languages, with specific material for reading and writing, culture of citizenship, environment, 
cultural practices and linguistics. However, no evidence of this was found on this website either. This redirected this research study to the local ministries of education with the larger number of IP: Chiapas, Oaxaca, and Yucatan.

On the website of the Ministry of Education of Chiapas, two links were available: Aprende en casa (Learn at home), which provides the timetable for the TV programs already described, and $M i$ escuela en casa (My school at home), described below (Box 2).

\section{BOX 2 MI ESCUELA EN CASA}

$\begin{array}{lcc}\text { Material } & \text { Available in Spanish } & \text { Available in an indigenous language } \\ \text { students } & \text { yes } & \text { no } \\ \text { teachers } & \text { yes } & \text { no } \\ \text { parents } & \text { yes } & \text { no }\end{array}$

Source: Elaborated by the authors based on information published by the Ministry of Education of Chiapas.

A closer look at this shows over 50 materials in Spanish for students, teachers, and parents with activities, links, PDFs, videos, and even radio shows. Although it is divided in different categories, the content is similar; however, it is addressed to different audiences. In addition, booklets for kindergarten, elementary school, and middle school are also available. They are written in Spanish and four indigenous languages (Box 3): Chol, tseltal, tsotsil, and tojol-ab'al (Ministry of Education of Chiapas, n.d).

\section{BOX 3 MATERIAL AVAILABLE IN SPANISH AND IN AN INDIGENOUS LANGUAGE}

\begin{tabular}{lcc} 
Material & $\begin{array}{c}\text { Number of pages written in Spanish } \\
\text { Kindergarten }\end{array}$ & $\begin{array}{c}\text { Number of pages written in an } \\
\text { indigenous language }\end{array}$ \\
Elementary School & 46 & 16 \\
Secondary School & 117 & 21 \\
\hline
\end{tabular}

Source: Elaborated by the authors based on information published by the Ministry of Education of Chiapas.

The Ministry of Education of Oaxaca (2020) provides five links in Spanish: Scholarship for basic education, Full time elementary schools, See well to learn better, Learning at the hospital, English language program, and the National school life program. None of these links provides material for learning in any language other than Spanish. The Ministry of Education of Yucatán (2020) provides PDFs in Spanish for kindergarten, elementary school, middle school and special education (Box 4). 


$\begin{array}{lcc}\text { Material } & \text { Available in Spanish } & \text { Available in an indigenous language } \\ \text { kindergarten } & \text { yes } & \text { yes } \\ \text { elementary school } & \text { yes } & \text { yes } \\ \text { secondary school } & \text { yes } & \text { no } \\ \text { special education } & \text { yes } & \text { no }\end{array}$

Source: Elaborated by the authors based on information published by the Ministry of Education of Yucatán.

Although it seems that the Ministry of Education of Yucatan offers inclusive material for indigenous and non-indigenous students, the material is quantitatively different. For kindergarten there are 21 links in Spanish to support education, whereas there are only two links in the local indigenous languages that describe general activities for a week. For elementary school, 27 activities are available in Spanish and 10 activities are written in Mayan. As for middle school and special education, the material is available in Spanish only.

In addition, all these initiatives are based on the assumption that parents can help with the learning of their children. However, INEGI (2015) shows that almost 23\% of the indigenous population are illiterate, which might mean that the parents of indigenous children may not be able to give them the kind of help they need, putting them at a further disadvantage.

\section{CONCLUSION}

The political framework in favor of IP reflects the position of Mexico in terms of human and cultural rights. This political and legal structure seeks to foster fairness and equal access to education, with special provisions for vulnerable groups, such as indigenous peoples. Nevertheless, given the fact that 68 indigenous languages and 364 language varieties are spoken in the national territory, efforts to make educational resources (videos, PDFs, radio and TV shows, web pages, and the like) available to every ethnic group in the land, in their own language, may still be deemed as quite limited. The number of languages and language varieties poses a formidable challenge in terms of the language barriers that need to be overcome to provide equal education for all in a language everyone can understand.

The COVID-19 pandemic has made it clear that educational measures, whether intentionally or not, are biased in favor of monolingual Spanish-speaking learners, with limited materials produced in indigenous languages. This perpetuates the tendency to ignore or disregard minoritarian languages in favor of those that are dominant, as is the case of Spanish. Thus, in the wake of the COVID-19 health crisis, the constitutional right of indigenous peoples to quality education is compromised even more deeply.

Most of the materials available whether online, in print or on video, are in Spanish, with a reduced number of materials available in indigenous languages. These results are similar to those of INEE (2017), which makes reference to the lack of relevant or local language materials needed for class. Likewise, access to information and communication technologies, such as smart TVs, cell phones, and 
RAP | The impact of COVID-19 on education provision to indigenous people in Mexico

the Internet-precisely the type of gadgets and services that are crucial to education in COVID-19 times - is significantly lower in indigenous households in comparison with the mainstream population. As a result of this, the perpetual inequality in educational services for impacted groups in our country is aggravated by the lack of material, available remotely, in all Mexican indigenous languages. This may be considered as a form of discrimination, esp., when we consider the resources available for Spanish speaking students (CONAPRED, 2011). Furthermore, even if the amount of educational services and resources allocated to alleviate the effects of COVID-19 on education were the same for everyone, inequality of access by vulnerable ethnic groups would limit their effectiveness considerably

In addition, little is known about what happens in Mexican indigenous and rural zones in terms of local initiatives in favour of education. A search into state and national archives and publications that assess the effect of such actions and programs reveals that there is no information available about the impact of educational policies implemented by the federal and state governments. Well-documented research is urgently needed to find out what is happening on the ground and evaluate how institutional policies are having an effect in the population in question.

In the absence of a readily available vaccine that in the near future could mitigate the spread of the COVID-19, it can be safely projected that the negative educational implications of the pandemic in Mexican indigenous populations could be further exacerbated by the already existing structural social, health, and economic inequalities. On a final note, the present study recommends that considerable state funding be set aside to funnel educational resources to indigenous groups, in their own language, to alleviate the educational crisis brought about by the COVID-19 pandemic. 


\section{REFERENCES}

Castañeda, M. (2015). El derecho internacional de los derechos humanos y su recepción nacional. México, DC: CNDH México.

Cohen, L., Manion, L., \& Morrison, K. (2007). Research methods in education ( $6^{\text {th }}$ ed.). London, UK: Routledge.

Comisión Estatal de Derechos Humanos de Nuevo León. (n.d.). Pactos, convenios y tratados internacionales suscritos y ratificados por México, incluyendo la Declaración de los Derechos Humanos. Retrieved from https://www.cedhnl.org.mx/somos/ legislacion/08.pdf

Comisión Nacional de la Población. (2015). Infografía: población indigena. Retrieved from https://www.gob.mx/cms/uploads/attachment/ file/121653/Infografia_INDI_FINAL_08082016.pdf

Comisión Nacional para el Desarrollo de los Pueblos Indígenas. (2015). Indicadores socioeconómicos de los pueblos indígenas de México. Retrieved from https://www.gob.mx/cms/uploads/attachment/ file/239921/01-presentacion-indicadoressocioeconomicos-2015.pdf

Consejo Nacional de Evaluación de la Política de Desarrollo Social. (2019). La pobreza en la población indígena de México, 2008-2018. Retrieved from https://www.coneval.org.mx/ Medicion/MP/Documents/Pobreza_Poblacion_ indigena_2008-2018.pdf

Consejo Nacional para Prevenir la Discriminación. (2011). Encuesta Nacional de Discriminación: Resultados sobre diversidad cultural. Retrieved from http://www.conapred.org.mx/userfiles/files/EnadisDC-INACCSS.pdf

Consejo Nacional para Prevenir la Discriminación. (2018). Ficha temática Pueblos Indígenas. Retrieved from https://www.conapred.org.mx/userfiles/files/ Ficha\%20Pindigenas(1).pdf

Diario Oficial de la Federación. (2001, August 14). Programa Especial de los Pueblos Indígenas. Retrieved from https://www.dof.gob.mx/nota_ detalle.php? codigo $=762221 \&$ fecha $=14 / 08 / 2001$

Gobierno de México. (2020). Covid-19: Información general. Retrieved from https://coronavirus.gob. $\mathrm{mx} /$ datos/
Instituto Estatal de Educación de Oaxaca. (2020). Programas. Retrieved from https://www.oaxaca.gob. $\mathrm{mx} /$ ieepo/programas/

Instituto Nacional de Estadística, Geografía e Informática. (2015). Encuesta Intercensal 2015. Principales resultados. Retrieved from https:// www.inegi.org.mx/contenidos/programas/ intercensal/2015/doc/eic_2015_presentacion.pdf

Instituto Nacional para la Evaluación de la Educación. (2017). La educación obligatoria en México: informe 2017. México, DC: INEE.

Loeb, S., Dynarski, S., McFarland, D., Morris, P., \& Reardon, S. (2017). Descriptive analysis in education: A guide for researchers. Washington, DC: National Center for Education Evaluation and Regional Assistance.

Merino, M. (2015). Desiguales, invisibles y excluidos: Discriminación presupuesta-ria y grupos vulnerables, 2010-2013. México, DC: Centro de Investigación y Docencia Económicas y Consejo Nacional para Prevenir la Discriminación.

Ministry of Education of Chiapas. (n.d.). Mi escuela en casa. Retrieved from http://www. educacionchiapas.gob.mx/miescuela/index.html

Ministry of Education of Oaxaca. (n.d.). Instituto Estatal de Educación Publica de Oaxaca. Retrieved from https://www.oaxaca.gob.mx/ieepo/

Ministry of Education of Yucatan. (2020). Recursos educativos para aprender en casa. Retrieved from http://recursoseducativos.segey.gob.mx/

Mogalakwe, M. (2009). The Documentary Research Method - Using Documentary Sources in Social Research. Eastern Africa Social Science Research Review, 25(1), 43-58. Retrieved from http://doi. org/10.1353/eas.0.0006

Paré, L., Robles, C., \& Cortes, C. (2002). Participation of indigenous and rural people in the construction of developmental and environmental public policies in Mexico. IDS Bulletin, 33(2), 83-90.

Programa de Naciones Unidas para el Desarrollo. (2010). Informe sobre el desarrollo humano de los pueblos indígenas de México. Retrieved from http:// planipolis.iiep.unesco.org/upload/Mexico/Mexico_ HDR_2010.pdf 
Schmelkes, S. I. (2013). Educación y pueblos indígenas: problemas de medición. Realidad, datos y espacio Revista internacional de estadística $y$ geografía, 4(1), 5-13.

Scott, J. P. (Ed.). (2006). Documentary research. Thousand Oaks, CA: Sage Publications.

Secretaria de Educación Pública. (2020, March 14). Comunicado conjunto No. 3 presentan Salud y SEP medidas de prevención para el sector educativo nacional por COVID-19. Retrieved from https://www.gob.mx/sep/es/articulos/ comunicado-conjunto-no-3-presentan-salud-y-sepmedidas-de-prevencion-para-el-sector-educativonacional-por-covid-19?idiom $=$ es

Secretaría de Educación Pública. (2020, March 29). Comunicado conjunto No. 3 presentan Salud y SEP medidas de prevención para el sector educativo nacional por COVID. Retrieved from https:// www.gob.mx/sep/es/articulos/boletin-no-75transmitiran-sistemas-publicos-de-comunicacioncontenidos-educativos-durante-el-receso-escolarpreventivo-por-covid-19?idiom=es

Secretaría de Educación Pública. (2020, April 24). Boletín No. 102 Inicia SEP estrategia radiofónica para comunidades indígenas del programa Aprende en Casa. Retrieved from https://www.gob.mx/sep/ articulos/boletin-no-102-inicia-sep-estrategiaradiofonica-para-comunidades-indigenas-delprograma-aprende-en-casa?idiom=es

Secretaría de Educación Pública. (2020, April 27). Boletín No. 106. La inclusión parte fundamental del programa aprende en casa: Esteban Moctezuma Barragán. Retrieved from https://www.gob.mx/sep/ articulos/boletin-no-106-es-la-inclusion-partefundamental-del-programa-aprende-en-casaesteban-moctezuma-barragan

Solís, P. (2017). Discriminación estructural y desigualdad social: con casos ilustrativos para jóvenes indígenas, mujeres y personas con discapacidad. México, DC: Conapred-CEPAL.

Tauli-Corpu, V. (2005). IPs and the Millennium Development Goals. Indigenous Perspectives, 7(1), 513-540.
Tollefson, J. (2009). Critical theory in language policy. In T. Ricento (Ed.), An introduction to language policy: theory and method. (Chap. 3, pp. 42-59). Hoboken, NJ: Blackwell publishing.

United Nations. (n.d.). Indigenous peoples at the United Nations. Retrieved from https://www. un.org/development/desa/indigenouspeoples/ about-us.html

United Nations Educational, Scientific and Cultural Organization. (2019). National learning platforms and tools. Retrieved from https://en.unesco.org/ covid19/educationresponse/nationalresponses

United Nations Educational, Scientific and Cultural Organization. (2020, April 27). Frente educativo: respuestas al COVID. Retrieved from https:// es.unesco.org/mexicoreune/educacion

United Nations Educational, Scientific and Cultural Organization. (2020, May 10). COVID-19 Educational disruption and response. Retrieved from https://en.unesco.org/covid19/educationresponse

United Nations Educational, Scientific and Cultural Organization. (n.d.). Adverse consequences of school closures. Retrieved from https://en.unesco.org/ covid19/educationresponse/consequences

United Nations International Children's Emergency Fund. (2018). Panorama educativo de la población indigena y afrodescenciente 2017. México, DC: UNICEF \& Instituto Nacional para la Evaluación de la Educación.

Velasco Pavón, J. C. P. (2014). Economic behavior of IPs: the Mexican case. Latin American Economic Review, 23(1), 1-58.

World Health Organization. (2020, April 17). Q\&A on coronaviruses (COVID-19). Retrieved from https://www.who.int/emergencies/diseases/novelcoronavirus-2019/question-and-answers-hub/q-adetail/q-a-coronaviruses

World Health Organization. (2020, May 21). Coronavirus disease (COVID-19) Pandemic. Retrieved from https://www.who.int/emergencies/ diseases/novel-coronavirus-2019 
RAP | The impact of COVID-19 on education provision to indigenous people in Mexico

\section{Elida Sánchez-Cruz}

https://orcid.org/0000-0002-3092-543X

Ph.D. in Education; Professor in Faculty of Languages at Universidad Veracruzana. E-mail: elisanchez@uv.mx

\section{Alfred Masinire}

https://orcid.org/0000-0002-1329-8569

$\mathrm{Ph} . \mathrm{D}$. in Education; Senior lecturer in Faculty of Education at University of the Witwatersrand.

E-mail: alfred.Masinire@wits.ac.za

\section{Enrique Vez-López}

https://orcid.org/0000-0003-1117-5386

Ph.D. in Language Sciences; Professor in Faculty of Languages at Universidad Veracruzana. E-mail: evez@uv.mx 